\title{
Analyzing Transnational Relations of Local Literacy Groups through the Collective Identity Approach
}

\author{
Aswin Baharuddin ${ }^{1}$, Adelita Lubis ${ }^{2}$, Mia Aulina Lubis ${ }^{3}$, Fara Fahira $^{4}$, Rahmatia $^{5}$, Firdaus ${ }^{6}$ \\ \{sawingbahar@gmail.com ${ }^{1}$, adelita.lubis@gmail.com ${ }^{2}$, mialubis@gmail.com ${ }^{3}$ \} \\ Department of International Relation, Faculty of Social and Political Sciences, Universitas \\ Hasanuddin, Jl. Perintis Kemerdekaan KM 10, Makassar, Indonesia 1,4,5,6 \\ Department of International Relation Universitas Fajar, Jl. Prof. Abdurahman Basalamah No.101, \\ Makassar, Indonesia ${ }^{2}$ \\ Universitas Sumatera Utara, Jl. Abdul Hakim No. 1, Medan, Indonesia ${ }^{3}$
}

\begin{abstract}
This study aims to analyze the transnational activities of Community-Driven Literacy Groups in Makassar. This research was conducted in the city of Makassar in 2019. This study was qualitative. Data collection techniques used in this study were in-depth interviews, observation and document review. The informants in this study were activists from 5 literacy communities in Makassar, namely Kedai Buku Jenny, Kampung Buku, Rumata 'Art Space, Philosophia, and Kata Kerja. This study found that Community-Driven Literacy Groups in Makassar already have an international network. The international network was built through local community initiatives. Transnational relations can be developed through narratives formulated by local literacy groups and then affirmed by international partners as their collective identity.
\end{abstract}

Keywords: Literacy Groups, Makassar, Collective Identity, Transnational Relations

\section{Introduction}

International Relations, as a dynamic study, is greatly affected by changing global contexts. The high intensity of transnational interaction makes this study experience an expansion of issues, actors and methodologies. This can be traced through the dichotomy of high politics and low politics after the cold war ended. High politics issues, including international security and sovereignty dominated by state actors, are no longer the only options in the study of International Relations. Low politics topics such as economics, environment, culture, and education then become a concern for International Relations researchers. One interesting issue for further elaboration is the issue of education. Education becomes very crucial because of the quality of education in a country is considered to determine how the quality of the country. In a sense, the ability and intelligence of the people can contribute to the achievement of the goals of the state so that everyone has the right to access education. Therefore, the state should facilitate educational facilities and infrastructure so that its citizens can get a good education. 
According to UNESCO's report on education delivered in the Ethiopian capital, Addis Ababa, the condition of education in the world is need more attention. [1]. In the report, UNESCO [1] stated that 57 million children worldwide did not go to school, while 774 million adults worldwide were illiterate. This shows the vast inequality of opportunities to obtain an education. Global data is also in tune with the situation of Education in Indonesia. Indonesia's education is ranked 64th for education worldwide from a total of 120 countries. [1]. According to statistics from UNESCO, from a total of 61 countries, Indonesia is ranked 60th with a low literacy level. 59th place is filled by Thailand, and Botswana fills the last place. While Finland is ranked first with a high literacy level, almost reaching 100\%. [1]. This data clearly shows that the high reading interest in Indonesia is still far behind Singapore and Malaysia. Other research data conducted by the United Nations Development Program (UNDP) [1], although Indonesia has invested many resources in the field of education. Education dominates Indonesia's social spending, and $20 \%$ of Indonesia's budget allocated in the education level based on the Human Development Index (HDI) in Indonesia is still relatively low, which is $14.6 \%$. This percentage is far lower than Malaysia, which reached 28\% and Singapore, which reached 33\% [1].

The data above shows that Indonesia is still experiencing problems in the field of education. This problem is not enough just to be responded by the government, but all parties. The big problem above seems to be essential for the local literacy groups in Makassar. This research found 25 literacy communities that are active in Makassar. Some communities have been active for more than five years such as Rumata 'Art Space, Kampung Buku, Kedai Buku Jenny, Philosophia and Kata Kerja. This community is driven literacy groups seek to present alternative spaces to bring literacy closer to audiences from various work backgrounds and ages. In its journey, these literacy communities were identified as being able to build networks on a global scale. This is certainly interesting considering that these communities are self-supporting and voluntary-based, but they can contribute to solving education problems. Furthermore, local literacy groups have access to build and bind international networks to contribute to improving the quality of education and literacy in Indonesia, especially in Makassar.

\section{Research Method}

This research uses qualitative research and is carried out in Makassar City. Qualitative research is an approach to explore and understand the meaning of several individuals or groups of people ascribed to social and humanitarian problems [2]. The data in this study consisted of primary data and secondary data. Primary Data is data obtained from informants or research objects. Primary data in this study were obtained through direct interviews or by observation methods related to research topics that are equipped with written notes or by using recording aids, such as voice recorder. Secondary data is data obtained through data collection techniques that support primary data or by intermediaries and not directly. Secondary data in this study are books, journals, research reports or archives, both published and unpublished.

Data collection techniques used in this study were in-depth interviews, observation and document study. Interviews were conducted with activists from 5 literacy groups in Makassar. Furthermore, observation is a method of collecting data by observing activities carried out by the literacy groups in Makassar, then recording essential events related to the research topic. Next is the literature study is a data collection technique sourced from documents, books, journals and other scientific articles that support the implementation of research. 
Data processing in this study begins with the process of selecting data related to research, compiling data, classifying data as an effort to classify, classify, and sort data based on specific classifications determined by researchers. Next is the processing of data that has been classified and then the data is analysed and continued with the preparation of written based on data that has been prepared logically and systematically. The data analysis technique in this research is descriptive argumentative which sees social traditions that are realized in the perspective of the beliefs of the object of research. The next step, the researcher formulates a conclusion that contains the essence of the whole set of research activities. The technique used in concluding is the result of proper data processing and analysis. The conclusion drawn is based on the results of the discussion of the formulation of the problem raised by the researcher, so the researcher focuses on the data from interviews, observations, and data collection from scientific journals and books - the principle used in making conclusions that can be accounted for.

\section{Result and Discussion}

The urgency regarding the discussion of non-state actors in the study of International Relations can be traced through several excellent references including Power and Interdependence [3], Transnational Relations and World Politics [4] and "Bringing Transnational Relations Back In [5]. These references put forward the proposition that the study of International Relations is no longer sufficient if it only focuses on the activities of the state and its relation to the threat of sovereignty. International Relations Studies must be able to respond to the latest global changes, such as the emergence of non-state actors and nontraditional issues.

Keohane and Nye emphasized the increasing role of non-state actors through inter-societal intercourse. Interaction phenomena such as this, encourage the birth of a transnational relationship model that is different from international relations focusing on state-to-state relationships. Specifically, transnational relations can be defined as "contacts, coalitions and interactions across state boundaries that are not controlled by the central foreign policy organs of government". Furthermore, Transnational Relations as "the movement of tangible or intangible items across state boundaries when at least one actor is not an agent of government or an international organization" [4]. James Rosenau further defines transnationalism as "the process by which international relations carried out by the government have been accompanied by the relations of individuals, groups and private communities which can have significant consequences for the occurrence of various events [6].

From the elaboration above, in general, transnational relations can be defined as the crosscountry mobility of actors or entities, both individuals and groups in the economic, social, cultural, and so on. The intended actors are non-state actors such as Individuals, Transnational Corporations (TNC), Organized Crime Groups and Non-Organization Organizations (NGOs) or Civil Society Organizations (CSOs).

This research focuses on mapping and analyzing one of the non-state actors who carry out transnational interactions, namely Non-Organization Organization or Civil Society Organization (CSO). The term "non-governmental organization" can be traced back to the United Nations (UN) in its official statement in 1950. At present, the UN defines NGOs as "any non-profit, voluntary citizens' group which is organized on a local, national or international level. Task-oriented and driven by people with common interests, NGOs perform a variety of services and humanitarian functions, bring citizens' concerns to governments, monitor policies 
and encourage political participation at the community level. They provide analysis and expertise, serve as early warning mechanisms and help monitor and implement international agreements. Some are organized around specific issues, such as human rights, the environment or health" [7].

In more detail, NGOs can be characterized as organizations that (1) provide useful goods or services intended for the public, (2) are not allowed to distribute profits to people in their capacities, (3) their activities are based on voluntary zeal, (4) shows the values of rationality, often based on a robust ideological framework. Teegen [7] also proposed a definition of NGOs, namely as private organizations (non-state), non-profit organizations that aim to help the interests of the community in specific fields through advocacy and / or striving for social, political and economic goals such as equality, health, education, protection human rights and the environment. Historically the phenomenon of cross-border interaction by non-state actors, especially civil society groups, can be explored since the 19th century [8]. Transnational interactions are structural and actor-centred; in this context, this study focuses on analyzing transnational activities of 5 local literacy groups in Makassar.

There are several similar studies and related to the theme of the efforts of volunteer organizations to respond to problems in a country. The research was conducted Tiessen and Lough [9] trying to find out whether the presence of international volunteers can contribute positively or negatively to the capacity building of the Volunteer Partner Organization (VPO), an organization that invites international volunteers to come to their country. The Tiessen and Lough [9] study consider the considerations given by VPO that can contribute effectively to volunteering practices. The findings include several mitigating factors - such as the duration of volunteering, collaboration with local volunteers, language skills and skills of volunteers, and training required - all of which play a role in determining the perception of success in capacity building and the skill transfer process.

The study also shows that collaboration between local volunteer teams and international volunteers that are oriented towards skills development can strengthen the process of sharing knowledge and can also ensure the continuity of capacity building after international volunteers return to their countries. Highly trained volunteers who come from high-income countries and take part in volunteering programs that are of short duration are more often associated with abilities in mastering capacity building. They are more trusted to be able to transfer skills better. The study also shows the importance of collaboration with local volunteer teams combined with efforts to understand the traditions of indigenous people. Besides, the capacity possessed by international volunteers in applicable skills is far more valued compared to the level of education possessed by those volunteers. Another finding is that the long duration of the volunteering program does not guarantee the smooth process of capacity building.

Subsequent studies conducted by Jakimow [10] focused on volunteer ways in a development program in the city of Medan in using opportunities created by the state for the volunteering process to critique government practices and also the traditions of its inhabitants. Jakimouw's findings found that volunteers consider the relationships that should be formed between citizens and their countries need to be based on caring relationships, not relationships based on welfare distribution. The volunteers suggested that their position outside the formal structure of the state allowed them to build better relations with the population. Thus, volunteers create a role for themselves in development following the direction of the state to become a bridge between the state and society. Unfortunately, the finding found that voluntary engagement with the state associations with norms and practices that constitute it - limits their ability to form practices of relations with the population. 
Also, Nelson and Child's [11] research also found that international voluntary service (IVS) has gained much focus from researchers. However, the organizations that play a role behind the international voluntary program are still lacking attention. The focus of Nelson and Child's research lies in how these organizations provide IVS experience for IVSO, local NGOs, and volunteers in India. Their findings have an impact on scholars and practitioners, where students who are interested in international volunteering, in general, cannot ignore organizations that facilitate IVS. At the same time, those who are interested in the results obtained by students will be better able to develop more holistic explanations if they consider organizations that mediate the experiences of the volunteers. For them, practitioners might be warned about the importance of treating their partners more strategically.

Of the three cutting-edge scientific publications above, the three focus more on the efforts of voluntary-based Organizations or Communities to present solutions to their domestic problems by maximizing their internal resources, in other words, the strategy is inward-looking. The difference with this proposed research is that this research dialectically tries to analyze global or transnational variables that enable voluntary community-based people to accelerate efforts to achieve their program goals.

In this study, five respondents were interviewed who were representatives of 5 local literacy groups in Makassar. Literacy groups include Kampung Buku, Kedai Buku Jenny, Philosophia, Kata Kerja, and Rumata' Art Space. The literacy community aims to increase and accelerate people's interest in literacy through the work programs of these communities. These local literacy groups even lasted for more than five years. This research found that in the implementation of the program, the local literacy groups have moved to build an international network. Of the five communities that we interviewed, four of them had international networks. At present, Kampung Buku has been connected to a network of cultural programs in southeast Asia through the Mekong Cultural Hub. Besides, Rumata 'Art Space also has an international collaboration network in the Makassar International Writers Festival and Makassar Southeast Asia Screen Academy. Furthermore, Kedai Buku Jenny became part of a global communitybased in Japan, "Pecha Kucha Night" while the Kata Kerja Community has developed cooperation with Mars International for the development of literacy in Makassar.

Local literacy group can succeed in building international networks because of their ability to build narratives to form a collective identity. One explanation was explained by Alberto Melucci, who argues that collective identity is the process of forming a system of action. This collective identity is the result of interactions and shared ideas carried out by several individuals or groups about the orientation of action and the opportunities and challenges of implementing that action. Interacting and sharing is what makes Melucci define collective identity as a process. Because through this, the identity is then constructed and negotiated [12].This collective identity builds engagement between the local community and its international network.

\section{Conclusion}

This research concludes that in its efforts in responding to educational problems in Indonesia, the Local Literacy Groups can build and mobilize resources through international networks. Local literacy communities can succeed in building international networks because of their ability to build narratives to form a collective identity. This collective identity contributes to building coherence between the local community and its international network. 
Acknowledgements. We would like to thank the LPPM Hasanuddin University for funding this research.

\section{References}

[1] UNESCO (United Nations Educational Scientific and Cultural Organization): "Youth and skills: Putting education to work. Education for All Global Monitoring Report 2012.," UNESCO, Paris (2012)

[2] Creswell, J. W.: Educational research: Planning, conducting, and evaluating quantitative and qualitative research (3rd ed.), Upper Saddle River, NJ: Pearson Education, Inc (2008)

[3] Keohane, R and Nye, J. S.: Power and Interdependence: World Politics in Transition., Boston, MA: Little \& Brown (1977)

[4] Keohane, R. O and Nye, J. S.: Transnational relations and world politics. Harvard University Press, Harvard University Press (1972)

[5] Risse-Kappen, T. : Bringing Transnational Relations Back In: non-state actors, domestic structures and international institutions (Cambridge Studies in International Relations, pp. I-Vi), Cambridge: Cambridge University Press pp. I-Vi (1995)

[6] Rosenau, J. N.: The study of global interdependence: essays on the transnationalization of world affairs, Nichols Publishing Company (1980)

[7] Fakih, M.: Masyarakat Sipil untuk Transformasi Sosial: Pergolakan Ideologi di Dunia LSM Indonesia cetakan keempat, Yogyakarta: Penerbit Pustaka Pelajar, (2008)

[8] Keck, M. E and Sikkink, K.: Activists beyond borders: Advocacy networks in international politics, Cornell University Press (2014)

[9] Tiessen, R and Lough, B. J.:" International Volunteering Capacity Development: Volunteer Partner Organization Experiences of Mitigating Factors for Effective Practice.," Forum for Development Studies Routledge., Vol. 46 , no. 2, pp. 299-320 (2019)

[10] Jakimow, T.: " Volunteers' practices of care in community development as a model for citizenship in Medan, Indonesia," Citizenship Studies, Vol. 22, no. 2, pp. 145-159 (2018)

[11] K. Nelson and C. Child, "Adding the organizational perspective: How organizations shape service work abroad," VOLUNTAS: International Journal of Voluntary and Nonprofit Organizations, Vol. 27 , no. 2, pp. 525-548 (2016)

[12] Johnston, H and Klandermans, B.: "The Cultural Analysis of Social Movements," in Social Movements and Culture, vol. Minneapolis, Minneapolis, University of Minnesota Press, pp. 3-24 (1995) 